\title{
THE
}

1996

\section{The Auxin Transport Inhibitor N-(1-Naphthyl)phthalamic Acid Elicits Pseudonodules on Nonnodulating Mutants of White Sweetclover}

C. $\mathrm{Wu}$

University of Rhode Island

R. Dickstein

University of Rhode Island

A. J. Cary

University of Rhode Island

J. H. Norris

University of Rhode Island

Follow this and additional works at: https://digitalcommons.uri.edu/bio_facpubs

Terms of Use

All rights reserved under copyright.

\section{Citation/Publisher Attribution}

Wu, C., Dickstein, R., Cary, A. J., \& Norris, J. H. (1996). The Auxin Transport Inhibitor N-

(1-Naphthyl)phthalamic Acid Elicits Pseudonodules on Nonnodulating Mutants of White Sweetclover. Plant Physiology, 110(2), 501-510. doi: 10.1104/pp.110.2.50.

Available at: https://doi.org/10.1104/pp.110.2.501

This Article is brought to you for free and open access by the Biological Sciences at DigitalCommons@URI. It has been accepted for inclusion in Biological Sciences Faculty Publications by an authorized administrator of DigitalCommons@URI. For more information, please contact digitalcommons-group@uri.edu. 


\title{
The Auxin Transport Inhibitor N-(1-Naphthyl)phthalamic Acid Elicits Pseudonodules on Nonnodulating Mutants of White Sweetclover ${ }^{1}$
}

\author{
Chunfa Wu ${ }^{2}$, Rebecca Dickstein ${ }^{3}$, Andrew J. Cary ${ }^{4}$, and Joanna Hanks Norris* \\ Department of Biological Sciences, University of Rhode Island, Kingston, Rhode Island 02881-0812
}

\begin{abstract}
The collection of symbiotic (sym) mutants of white sweetclover (Melilotus alba Desr.) provides a developmental sequence of mutants blocked early in infection or nodule organogenesis. Mutant phenotypes include non-nodulating mutants that exhibit root-hair deformations in response to Rhizobium meliloti, mutants that form ineffective nodules lacking infection threads, and mutants that form infection threads and ineffective nodules. Mutant alleles from both the $s y m-1$ and the $s y m-3$ loci exhibited a non-nodulating phenotype in response to $R$. meliloti, although one allele in the sym-1 locus formed ineffective nodules at a low frequency. Spot-inoculation experiments on a non-nodulating allele in the sym-3 locus indicated that this mutant lacked cortical cell divisions following inoculation with $R$. meliloti. The auxin transport inhibitor $N$-(1-naphthyl)phthalamic acid elicited development of pseudonodules at a high frequency on all of the sweetclover sym mutants, including the nonnodulating mutants, in which the early nodulin ENOD2 was expressed. This suggests that $N$-(1-naphthyl)phthalamic acid activates cortical cell divisions by circumventing a secondary signal transduction event that is lacking in the non-nodulating sweetclover mutants. The sym-3 locus and possibly the sym- $\mathrm{J}$ locus appear to be essential to early host plant responses essential to nodule organogenesis.
\end{abstract}

Establishment of the nitrogen-fixing symbiosis between bacteria of the genus Rhizobium and specific leguminous host plants requires an exchange of signal molecules leading to expression of both bacterial and host plant genes involved in infection and root nodule organogenesis (reviewed by Denarie and Roche, 1992; Hirsch, 1992; Long, 1992). Specific flavonoid signals secreted by the host plant roots elicit the expression of essential bacterial nod genes that in turn produce modified lipo-oligosaccharide signals called Nod factors (Peters et al., 1986; Kosslak et al., 1987;

\footnotetext{
${ }^{1}$ This work was partially supported by the National Research Initiative Competitive Grants Program, U.S. Department of Agriculture, grant No. 91-37305-6584 to R.D. and grant No. 94-373111117 to J.H.N.

${ }^{2}$ Present address: Plant Cell Technologies, P.O. Box 1190, West Chatham, MA 02669.

${ }^{3}$ Present address: Department of Bioscience and Biotechnology, Drexel University, 32nd and Chestnut Streets, Philadelphia, PA 19104.

${ }^{4}$ Present address: Field of Botany, Section of Plant Biology, Cornell University, Ithaca, NY 14853.

* Corresponding author; e-mail jnorris@uriacc.uri.edu; fax 1-401$792-5974$
}

Maxwell et al., 1989; reviewed by Carlson et al., 1994). In particular, purified NodRm-IV(S) from Rhizobium meliloti elicits early host plant responses in alfalfa, including roothair deformation and cortical cell division, resulting in nodule organogenesis (Lerouge et al., 1990; Truchet et al., 1991). The recent report that Nod factors rescue a carrot embryogenesis mutant suggests that these factors may represent a class of chitin derivatives involved in initiation of meristematic cell divisions (De Jong et al., 1993).

Inoculation with a host-specific species of Rhizobium or Bradyrhizobium elicits cortical cell divisions within $24 \mathrm{~h}$ that develop into a nodule primordium (Turgeon and Bauer, 1982; Calvert et al., 1984; Dudley et al., 1987). Bacteria are released into cells of the emerging nodule from infection threads originating from tightly curled root-hair cells. The response of root-hair cells to Nod factors is very rapid (Ehrhardt et al., 1992; Heidstra et al., 1994) and more stringent in the structural requirements for the Nod factors than activation of cortical cell divisions (Ardourel et al., 1994). Other studies have shown that susceptibility of cortical cells to nodulation factors is not due to arrest of the cell cycle, and implicate the additional involvement of a factor released from the stele (Libbenga and Bogers, 1974; Yang et al., 1994). A mature indeterminate nodule infected by $R h i-$ zobium contains an apical meristematic zone, a prefixing zone in which differentiation of both symbionts occurs, a zone of cells containing nitrogen-fixing bacteroids, and a proximal zone in which senescence and degeneration of bacteroids takes place (nomenclature of Vasse et al., 1990).

Expression of nodule-specific genes of the host plant, termed nodulin genes, is correlated with early events in nodule development (Scheres et al., 1990b). The early nodulin ENOD2 is expressed in the nodule parenchyma of alfalfa, pea, and soybean nodules (Van de Wiel et al., 1990a, 1990 b). ENOD2 is also expressed in bacteria-free nodules elicited by exopolysaccharide (exo) mutants of $R$. meliloti or by Agrobacterium tumefaciens transconjugants carrying the R. meliloti nod genes (Dickstein et al., 1988; Van de Wiel et al., 1990a; Allen et al., 1991), as well as in spontaneous nodules that occur in the absence of Rhizobium (Truchet et al., 1989). The early nodulin MtENOD12 is expressed within 3 to $6 \mathrm{~h}$ in root epidermal cells following inoculation in transgenic alfalfa (Pichon et al., 1992) and in cells just

Abbreviations: ATI, auxin transport inhibitor; $\mathrm{Hac}^{+} /$Inf, roothair curling with infection threads; Had, root-hair deformation; NPA, N-(1-naphthyl)phthalamic acid 
ahead of the infection zone in nodules of pea (PsENOD12, Scheres et al., 1990a) and Medicago truncatula (Pichon et al., 1992). Most recently, a Rhizobium-induced peroxidase expressed transiently prior to infection in $M$. truncatula was reported (Cook et al., 1995).

The formation of spontaneous nodules or nodulation in the absence of Rhizobium in some lines of alfalfa (Truchet et al., 1989; Caetano-Anollés et al., 1990) and white clover (Blauenfeldt et al., 1994) suggests that the plant regulates nodule morphogenesis. The development of spontaneous nodules must overlap at least partially with the developmental pathway leading to Rhizobium-induced nodulation, since nodulins such as ENOD2 (Truchet et al., 1989) and ENOD12 (Pichon et al., 1994) are expréssed in these nodules. Spontaneous nodules also suppress nodulation of alfalfa by $R$. meliloti; likewise, nodules infected by $R$. meliloti suppress formation of spontaneous nodules (CaetanoAnollés et al., 1990). However, spontaneous nodules initiate primarily in the older portion of the root system, the pattern of ENOD12 expression in the nodule primordia is distinct from Rhizobium-induced nodulation, and systemic autoregulation does not occur in spontaneous nodulation, indicating that some differences in development from $\mathrm{Rhi}$ zobium-induced nodulation exist (Pichon et al., 1994).

It has been almost 60 years since Thimann (1936) first suggested that plant hormones, specifically auxin, regulate nodule development, a hypothesis supported by accumulating evidence that auxin and/or cytokinins, or gradients of these hormones, are involved in nodule organogenesis (Libbenga et al., 1973; reviewed by Hirsch and Fang, 1994). Application of an ATI has been shown to induce formation of nodule-like structures on a number of legumes (Allen et al., 1953). The nodule-like structures, also called pseudonodules, elicited by the ATIs NPA and 2,3,5-triiodobenzoic acid, express the ENOD2 and ENOD12 genes (Hirsch et al., 1989; Van de Wiel et al., 1990a; Scheres et al., 1992). Evidence that cytokinins are involved in nodule morphogenesis is provided by reports of ENOD2 expression in cytokinin-treated Sesbania roots (Dehio and de Bruijn, 1992) and in nodules elicited by $R$. meliloti nod mutants carrying the trans-zeatin secretion gene from $A$. tumefaciens (Cooper and Long, 1994). Nodule-like structures are also formed on a non-nodulating line of soybean following application of 2,4-D (Akao et al., 1991).

We recently reported the symbiotic phenotypes of a group of sym mutants of white sweetclover (Melilotus alba), representing five genetic loci (Kneen and LaRue, 1988; Miller et al., 1991), that included mutants blocked at roothair curling, mutants blocked at infection, and mutants that formed ineffective nodules in response to $R$. meliloti (Utrup et al., 1993). The single mutant allele characterized in the sym-3 locus was of particular interest because it exhibited limited root-hair deformations in response to $R$. meliloti but formed no nodules, suggesting that a secondary signal leading to nodule organogenesis may be lacking in this mutant.

In this study, we have characterized the phenotype of additional nodulation mutants of sweetclover, including non-nodulating alleles in both the sym-1 and the sym-3 loci.
We found that the ATI NPA elicited nodule-like structures, or pseudonodules, on all of the non-nodulating mutants, as well as on the mutants that form ineffective nodules with $R$. meliloti, in which the ENOD2 gene was expressed. Our data suggest that the products of the sym-1 and sym-3 loci of sweetclover are essential components of the signal transduction pathway leading to nodule morphogenesis.

\section{MATERIALS AND METHODS}

\section{Plant Material}

Nine isogenic mutant lines of white sweetclover (Melilotus alba Desr. cv U389, PI 165554) derived from wild-type cv U389 by mutagenesis with ethyl methanesulfonic acid or neutron radiation (Kneen and LaRue, 1988), kindly provided by Dr. Tom LaRue (Boyce Thompson Institute for Plant Research, Ithaca, NY), have been maintained by selfpollination for more than five generations in our laboratory. Complementation analysis has indicated that four genetic loci are represented among the nine mutants analyzed in this study, with allelic mutants available in the sym-1 and sym-3 loci (Miller et al., 1991; listed in Table I).

Plants were grown in sterile vermiculite in $12-\mathrm{cm}$ pots or 1-quart Mason jars with foam stoppers as previously described (Utrup et al., 1993). For nitrogen-fixing nodules, plants were inoculated with Rhizobium meliloti SU47 $48 \mathrm{~h}$ after planting. Alternatively, seedlings were given a single application of $20 \mu \mathrm{M}$ NPA (generously provided by Uniroyal Chemical Co., Middlebury, CT) 1 week after germination as described by Hirsch et al. (1989). The NPA application was prepared in nitrate-free modified Jensen's nutrient medium (Vincent, 1970), which was used for all additional watering of plants. For evaluation of the effect of nitrate, $5 \mathrm{~mm} \mathrm{KNO}_{3}$ and $5 \mathrm{~mm} \mathrm{CaNO}$ were added to the Jensen's nutrient medium containing NPA. Nodules and pseudonodules were harvested at 4 weeks, fixed, embedded in Paraplast (Monoject Scientific, St. Louis, MO), sectioned, stained with safranin, and counterstained with fast green as previously described (Jensen, 1962; Utrup et al., 1993).

\section{Statistical Analysis}

The data on the number of plants forming pseudonodules for all of the mutant lines and wild-type sweetclover were evaluated by the $\chi^{2}$ test for larger frequency tables to assess whether the observed frequencies of forming pseudonodules deviated significantly from the null hypothesis (Finney, 1980). In this case, the hypothesis was that the probability of forming pseudonodules is the same for all lines, whether mutant or wild type. Table II (observed data) was compared with a table of expected data, using an expected frequency value of 0.606 , obtained by summing all of the observed data, with $7 d f$. For $\chi^{2}$ values greater than 18.47, the hypothesis is rejected and the observed values for frequency of formation of pseudonodules are significantly different at the $99 \%$ probability level (Finney, 1980). 


\section{Spot-Inoculation Experiments}

Seedlings were grown on nodulation plates and inoculated with a concentrated culture of $R$, meliloti SU47 using a micromanipulator according to the method of Dudley et al. (1987). Two types of black, nontoxic ink were used interchangeably to mark the spot of inoculation: Pelikan drawing ink (Gunther Wagner, Germany) and Speedball water-soluble ink for block printing (Hunt Manufacturing Co., Statesville, NC). Neither caused detectable damage to the root. Inoculated roots were harvested at times from 24 $\mathrm{h}$ to $21 \mathrm{~d}$ after inoculation, fixed, and serially sectioned as above. The sectioned tissue was stained with a commercial. preparation of Gill No. 2 hematoxylin (Sigma) for 10 to 20 min before mounting with a permanent resin (Jensen, 1962). Serially sectioned roots of spot-inoculated wild-type and noninoculated wild-type and mutant roots (dye-spotted only) were compared with spot-inoculated mutant roots at each time.

\section{Northern Blot Analysis}

Total RNA was isolated from roots and nodules by precipitation with $\mathrm{LiCl}$ (Govers et al., 1985). Whereas nitrogenfixing nodules could be harvested cleanly, some attached root tissue was unavoidably harvested along with the smaller and more fragile NPA-elicited nodules. The concentration of the total RNA samples was estimated by spectrophotometric determination. Total RNA samples were also evaluated for equal intensity and integrity of rRNA bands by ethidium bromide staining. For blotting, 10 $\mu \mathrm{g}$ of total RNA were loaded in each lane of a $1 \%$ agarose gel containing formaldehyde (Sambrook et al., 1989) and transferred to a positively charged nylon membrane following electrophoresis (Boehringer Mannheim). RNA molecular weight standards (Boehringer Mannheim) were also run on the gel and visualized by ethidium bromide staining before blotting. The blot was prehybridized in $15 \mathrm{~mL}$ of solution containing $5 \times \mathrm{SSC}(0.75 \mathrm{M} \mathrm{NaCl}, 75 \mathrm{~mm}$ sodium citrate, $\mathrm{pH} 7.0$ ), $50 \%$ formamide, $0.02 \%$ SDS, $0.1 \% \mathrm{~N}$-lauroylsarcosine, $2 \%$ blocking reagent (Genius kit, Boehringer Mannheim), $20 \mathrm{~mm}$ sodium maleate, $\mathrm{pH} 7.5$, for $16 \mathrm{~h}$ at $42^{\circ} \mathrm{C}$. Hybridization was carried out at $42^{\circ} \mathrm{C}$ for $16 \mathrm{~h}$ in fresh prehybridization solution containing the denatured 273-bp insert of pB1-A2ENOD2 from alfalfa (Dickstein et al., 1988) labeled with digoxigenin-dUTP (Boehringer Mannheim). The membrane was washed twice for $5 \mathrm{~min}$ each in $2 \times \mathrm{SSC}$ containing $0.1 \%$ SDS at $25^{\circ} \mathrm{C}$, followed by two washes of $15 \mathrm{~min}$ each at $65^{\circ} \mathrm{C}$ in $0.5 \times$ SSC containing $0.1 \%$ SDS. All hybridization procedures and subsequent chemiluminescent detection were carried out according to the instructions in the Genius kit manual (Boehringer Mannheim).

\section{RESULTS}

Mutant Alleles in Both the sym-1 and sym-3 Loci Are NonNodulating Following Inoculation with $R$. meliloti

Our previous characterization of the nodulation phenotype and root-hair-curling response of five sweetclover sym mutants (Utrup et al., 1993) was limited to 100 to 300 plants of a single mutant allele from each sym locus. For this study, greater numbers of plants, as well as additional mutant alleles in the sym-1 and sym-3 loci, were tested for nodulation following inoculation with $R$. meliloti to determine whether nodules might be found on a small percentage of the mutant plants.

Non-nodulating alleles were found in two of the sweetclover sym loci analyzed in this study. As shown in Table I, three of the four sym-1 alleles formed no nodules following inoculation with $R$. meliloti SU47. Only BT62, the single sym-1 allele tested in our previous analysis (Utrup et al., 1993), formed white, non-nitrogen-fixing nodules. All three mutant alleles in the sym-3 locus formed no nodules on more than a total of 1600 inoculated plants.

Mutants in two additional sweetclover sym loci formed white, non-nitrogen-fixing nodules. The single mutant available in the sym-2 locus, BT59, formed white nodules on $25 \%$ of the plants inoculated with $R$. meliloti (Table I). Mutant BT71, the sole sym-5 mutant, exhibited white nodules on $13 \%$ of the inoculated plants. For all of the mutants that formed ineffective nodules in response to $R$. meliloti, the number of nodules per plant varied from 1 to 10 , distributed both on the tap root and lateral roots, as previously shown (Utrup et al., 1993).

\section{sym-3 Allele BT70 Exhibits No Cortical Cell Divisions in Response to $R$. meliloti}

The sym-3 alleles are of particular interest because they were all non-nodulating when inoculated with $R$. meliloti (Table I). sym-3 allele BT70 also exhibited only limited root-hair deformations in response to $R$. meliloti (Utrup et al., 1993). To elucidate the point at which nodule development is blocked in this sym-3 allele, we carried out spotinoculation assays of mutant BT70 seedlings with R. meliloti according to the method of Dudley et al. (1987). A total of

\begin{tabular}{|c|c|c|c|c|}
\hline Locus & Allele & $\begin{array}{c}\text { No. of } \\
\text { Plants } \\
\text { Inoculated }^{\text {Inoch }}\end{array}$ & $\begin{array}{c}\text { No. of } \\
\text { Plants } \\
\text { Nodulated }\end{array}$ & $\begin{array}{c}\text { Percentage } \\
\text { of } \\
\text { Nodulation }\end{array}$ \\
\hline \multirow[t]{4}{*}{ sym-1 } & BT35 & 220 & 0 & 0 \\
\hline & BT58 & 90 & 0 & 0 \\
\hline & BT62 & 1060 & 123 & 12 \\
\hline & ВТ64 & 430 & 0 & 0 \\
\hline sym-2 & ВТ59 & 1030 & 260 & 25 \\
\hline \multirow[t]{3}{*}{ sym-3 } & BT61 & 570 & 0 & 0 \\
\hline & ВТ69 & 280 & 0 & 0 \\
\hline & ВТ70 & 800 & 0 & 0 \\
\hline sym-5 & Bโ71 & 1080 & 145 & 13 \\
\hline Wild type & & 100 & $100^{\mathrm{b}}$ & 100 \\
\hline
\end{tabular}

a The number of plants inoculated varied because of availability of seeds. $\quad{ }^{b}$ Nodules on wild-type plants were pink and nitrogen fixing. 


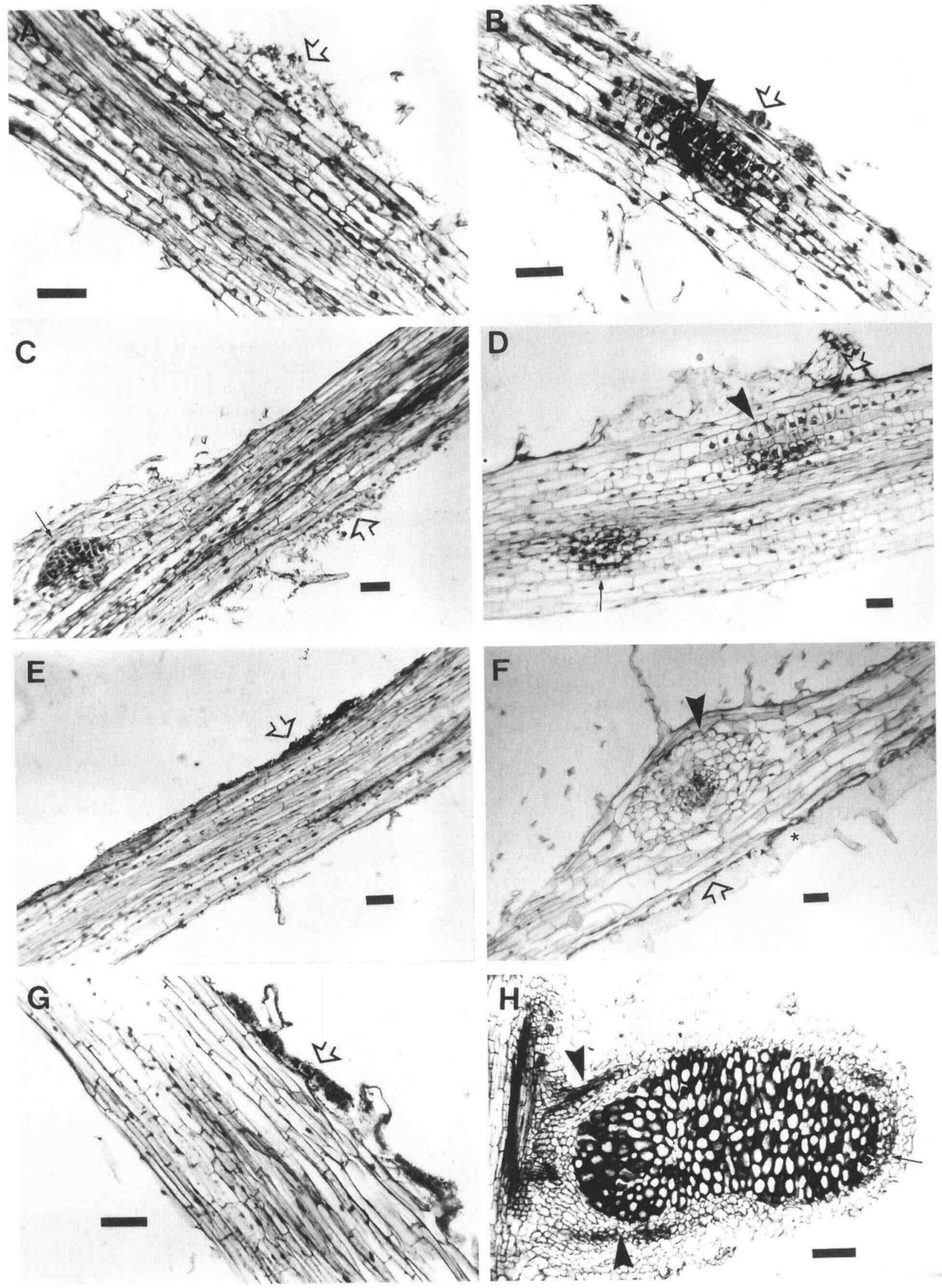


23 spot-inoculated seedlings of allele BT70 were examined by serial sectioning $48 \mathrm{~h}, 3 \mathrm{~d}, 4 \mathrm{~d}, 7 \mathrm{~d}$, and $11 \mathrm{~d}$ after inoculation and compared with an equal number of serially sectioned, spot-inoculated wild-type sweetclover seedlings, noninoculated wild-type seedlings, and noninoculated mutant seedlings at all times.

No nodules were observed on spot-inoculated BT70 plants, including plants maintained up to $28 \mathrm{~d}$ after inoculation. No activated regions of cortical cell mitoses or nodule primordia were observed in serially sectioned, spot-inoculated BT70 plants, shown at $48 \mathrm{~h}, 3 \mathrm{~d}, 7 \mathrm{~d}$, and 11 $\mathrm{d}$ after inoculation in Figure 1. In comparison, inner cortical cell mitoses were observed in about one-half of the spotinoculated wild-type plants at $24 \mathrm{~h}$ and in almost all wildtype seedlings at $48 \mathrm{~h}$ after inoculation (Fig. 1B). An emerging nodule primordium, often with a darkly staining infection thread (not shown), was observed at the dye spot in wild-type plants $3 \mathrm{~d}$ after inoculation (Fig. 1D). Nodules were clearly visible in spot-inoculated wild-type plants $7 \mathrm{~d}$ after inoculation (Fig. 1F). Only lateral root primordia were observed in serial sections of both mutant and wild-type noninoculated control plants (not shown).

\section{NPA Elicits Pseudonodules on All of the Sweetclover Nodulation Mutants}

In preliminary testing on wild-type sweetclover and mutants from all of the sym loci, approximately $80 \%$ of 60 seedlings treated with $20 \mu \mathrm{M}$ NPA $7 \mathrm{~d}$ after germination formed white pseudonodules similar to those observed on alfalfa (Hirsch et al., 1989), in comparison to pseudonodules formed on approximately $55 \%$ of the seedlings when treated with $200 \mu \mathrm{M}$ NPA. Seedlings of the mutants treated with NPA $14 \mathrm{~d}$ after germination formed fewer pseudonodules; approximately $55 \%$ of the seedlings treated with $20 \mu \mathrm{M} \mathrm{NPA}$ and $15 \%$ of the seedlings treated with $200 \mu \mathrm{M}$ NPA formed pseudonodules. Treatment with $20 \mu \mathrm{M}$ NPA 7 $\mathrm{d}$ after germination was chosen for further experiments.

No visible differences were apparent between the NPAelicited pseudonodules found on wild-type sweetclover (U389) and the pseudonodules formed on all of the mutants in the sym-1, sym-2, sym-3, and sym-5 loci; pseudonodules on sym-3 allele BT70 are shown in Figure 2. The number of pseudonodules on individual plants ranged from 1 to 12 white pseudonodules 4 weeks after application of $20 \mu \mathrm{M}$ NPA. The size of pseudonodules on an individual plant also varied, with an average diameter of about $1 \mathrm{~mm}$. Pseudonodules on wild type and all of the mutants were
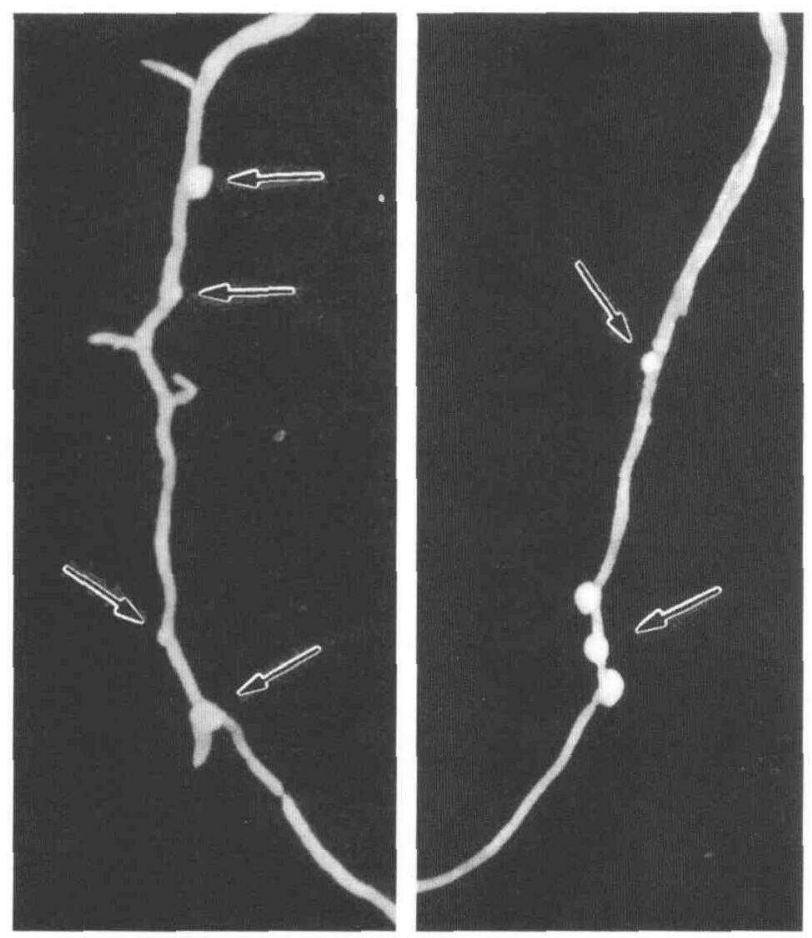

Figure 2. Pseudonodules elicited on an allele in the sym-3 locus of sweetclover following treatment with $20 \mu \mathrm{m}$ NPA. Small, spherical nodules of varying sizes are indicated by arrows along the primary root of two plants of allele BT70 4 weeks after NPA treatment. The lower portion of the root, containing no pseudonodules or lateral roots, was trimmed from each photograph.

found on the upper portion of the tap root, in the same region in which nitrogen-fixing nodules are formed on sweetclover plants inoculated with R. meliloti (Utrup et al., 1993), and were rarely found on lateral roots. The addition of $5 \mathrm{mM} \mathrm{KNO}_{3}$ and $5 \mathrm{mM} \mathrm{CaNO}_{3}$ did not inhibit formation of NPA-elicited pseudonodules on wild-type sweetclover but did block formation of nitrogen-fixing nodules on wildtype plants inoculated with $R$. meliloti.

All of the sweetclover mutants formed pseudonodules on 30 to $60 \%$ of the total number of plants treated with NPA, a rate slightly lower than observed for wild-type plants (Table II). All of the alleles in the sym-1 and sym-3 loci exhibiting a non-nodulating phenotype when inoculated with $R$. meliloti (Table I) formed large numbers of pseudonodules after NPA treatment. The number of plants that formed pseudonodules following NPA treatment of

\footnotetext{
Figure 1. (On facing page.) Spot inoculation of the sym-3 allele BT70 with $R$. meliloti. Seedlings of mutant and wild-type plants grown on nodulation plates were spot inoculated with $R$. meliloti strain SU 47 in the zone of emerging root hairs $48 \mathrm{~h}$ after germination. The inoculation spot was marked with dye, visible as particles marked by the open arrows (A-G). Fixed roots were serially sectioned and stained with hematoxylin and median longitudinal sections were compared with noninoculated controls (not shown) at each time. A, sym-3 allele BT70 $48 \mathrm{~h}$ after spot inoculation. B, Wild-type sweetclover $48 \mathrm{~h}$ after inoculation; arrowhead indicates a nodule primordium. C, sym-3 allele BT70 $3 \mathrm{~d}$ after inoculation; solid arrow indicates a lateral root primordium near the inoculation spot (open arrow). D, Wild type $3 \mathrm{~d}$ after inoculation; arrowhead indicates nodule primordium; arrow indicates lateral root primordium. E, sym-3 allele BT70 $7 \mathrm{~d}$ after inoculation. F, Oblique section of emerging nodule (arrowhead) on wild type $7 \mathrm{~d}$ after inoculation; star marks agar debris from nodulation plate. G, sym-3 allele BT70 $11 \mathrm{~d}$ after inoculation. H, Nitrogen-fixing nodule on wild-type sweetclover $21 \mathrm{~d}$ after inoculation; arrowheads indicate vascular tissue; arrow indicates nodule meristem. Bars $=50 \mu \mathrm{m}(\mathrm{A}-\mathrm{G}) ; 400 \mu \mathrm{m}(\mathrm{H})$. Downloaded from on July 13, 2018 - Published by www.plantphysiol.org

Copyright (c) 1996 American Society of Plant Biologists. All rights reserved.
} 
Table II. Frequency of formation of pseudonodules elicited by NPA on symbiotic mutants of sweetclover

Seedlings of wild-type and mutant sweetclover were grown in sterile vermiculite and treated with $20 \mu \mathrm{M}$ NPA 1 week after germination (Hirsch et al., 1989). White, spherical pseudonodules were harvested $28 \mathrm{~d}$ later.

\begin{tabular}{lcrcc}
\hline Locus & Allele & $\begin{array}{c}\text { No. of } \\
\text { Plants } \\
\text { NPA } \\
\text { Treated }^{\mathrm{a}}\end{array}$ & $\begin{array}{c}\text { No. of } \\
\text { Plants } \\
\text { with } \\
\text { Pseudonodules }^{\mathrm{b}}\end{array}$ & $\begin{array}{c}\text { Percentage of } \\
\text { Plants with } \\
\text { Pseudonodules }\end{array}$ \\
\hline sym-1 & BT35 & 380 & 160 & 42 \\
& BT58 & 660 & 420 & 64 \\
sym-2 & BT62 & 820 & 500 & 61 \\
sym-3 & BT59 & 2190 & 1380 & 63 \\
& BT61 & 240 & 82 & 33 \\
sym-5 & BT70 & 1120 & 630 & 56 \\
Wild type & BT71 & 990 & 620 & 63 \\
& & 1390 & 930 & 67
\end{tabular}

a The number of plants treated varied because of availability of seeds. ${ }^{b} \chi^{2}=65$, using the $\chi^{2}$ test for larger frequency tables (Finney, 1980), indicating that the observed differences in frequency of formation of pseudonodules are significant at the $99 \%$ probability level.

allele BT62 in the sym-1 locus was also greater than the number of plants that form ineffective nodules when this allele is inoculated with $R$. meliloti (compare to Table I). This observation was also true for mutants in the sym-2 and sym-5 loci that form ineffective nodules with $R$. meliloti (cf. Tables I and II).

The structure of pseudonodules elicited on the sweetclover mutants and wild-type sweetclover by NPA treatment was analyzed by paraffin serial sectioning (Jensen, 1962). Like pseudonodules elicited by ATIs on alfalfa (Hirsch et al., 1989) and Afghanistan pea (Scheres et al., 1992), the sweetclover pseudonodules were usually spherical in shape and lacked a clearly defined apical meristem, as shown in Figure 3. Abundant vascular tissue was present in the proximal and central portion of the pseudonodules, surrounded by a layer of smaller cells often filled with amyloplasts (not shown). The outer cells of pseudonodules on sym-1 alleles, the sym-5 mutant, and wild-type sweetclover (Fig. 3, A, B, E, and 3F) were larger and highly vacuolate and often resembled a nodule cortex, except that this layer of cells sometimes completely surrounded the pseudonodule (see Fig. 3B, for example). These pseudonodules also contained a densely delineated endodermal layer, clearly outlined under dark field (not shown). Occasionally, multilobed pseudonodules were observed in this group (Fig. 3, B and E). In pseudonodules from the sym-2 mutant and sym-3 alleles (Fig. 3, C and D), the outer cells were generally smaller and the endodermis was less apparent. However, the structure of pseudonodules observed on each mutant varied considerably within a range encompassed by the examples shown in Figure 3.

\section{The NPA-Elicited Pseudonodules Express the ENOD2 Gene}

To assess whether the pseudonodules elicited on the sweetclover mutants by NPA expressed nodulin genes, we analyzed total RNA for expression of the ENOD2 gene by northern blot analysis using a heterologous probe from alfalfa (Dickstein et al., 1988). As shown in Figure 4, the ENOD2 probe hybridized to RNA from nitrogen-fixing wild-type nodules infected by $R$. meliloti (lane 1 ), as well as to RNA from NPA-elicited pseudonodules on the nodulating sym-1 allele BT62, the sym-2 mutant, sym-3 allele BT70, and the sym-5 mutant (lanes 2-5). No hybridization occurred in lane 6 , which contained RNA from untreated wild-type sweetclover roots. The transcript hybridizing to the ENOD2 probe was determined to be $1.3 \mathrm{~kb}$ in size by comparison to RNA molecular weight standards (data not shown). Possibly because the tissue samples used for RNA isolation unavoidably contained attached root tissue, the level of hybridization observed for NPA-elicited pseudonodules on each mutant varied between samples; no quantitative conclusion regarding the level of hybridization should be drawn from the northern blot shown in Figure 4. However, ENOD2 expression was observed in all of the NPA-elicited pseudonodules from all of the mutants tested. No ENOD2 expression was detected in roots from mutant control plants that were not treated with NPA (not shown).

\section{DISCUSSION}

In this study, nodulation of wild-type and symbiotic mutants of sweetclover has been examined in detail using both $R$. meliloti and the ATI NPA to elicit nodules. Not unexpectedly, we found that NPA elicited nodule-like structures, or pseudonodules, on the roots of wild-type sweetclover similar to those observed on alfalfa treated with NPA (Hirsch et al., 1989). We also discovered that NPA elicited pseudonodules on the roots of seven sweetclover nodulation-defective mutants, representing four distinct genetic loci (Miller et al., 1991). This included an allele in the sym-3 locus that was shown to be deficient in its ability to undergo cortical cell divisions following spot inoculation of roots with $R$. meliloti.

We previously characterized the phenotype of a single mutant from each of five genetic loci required for symbiosis in white sweetclover and found that each mutant was blocked at a distinct stage of infection or early nodule development (Utrup et al., 1993). An allele from the sym-3 locus exhibited the most profound nodulation deficiency: only a limited $\mathrm{Had}^{+}$response was observed after inoculation of this mutant with $R$. meliloti. The single mutant in the sym-5 locus and one allele from the sym-1 locus were found to have phenotypes similar to that of wild-type alfalfa treated with purified NodRm-IV(S) (Truchet et al., 1991): root hairs were deformed or branched in response to $R$. meliloti and ineffective white nodules were formed. The single sym-2 mutant had the most advanced phenotype, producing white, ineffective nodules containing infection threads after inoculation with $R$. meliloti. The single mutant available in the sym-4 locus did not appear to be part of the same developmental sequence suggested by the phenotypes of the other mutants, because it exhibited infection threads but only rarely formed either ineffective or nitrogen-fixing nodules. This mutant was not further analyzed 

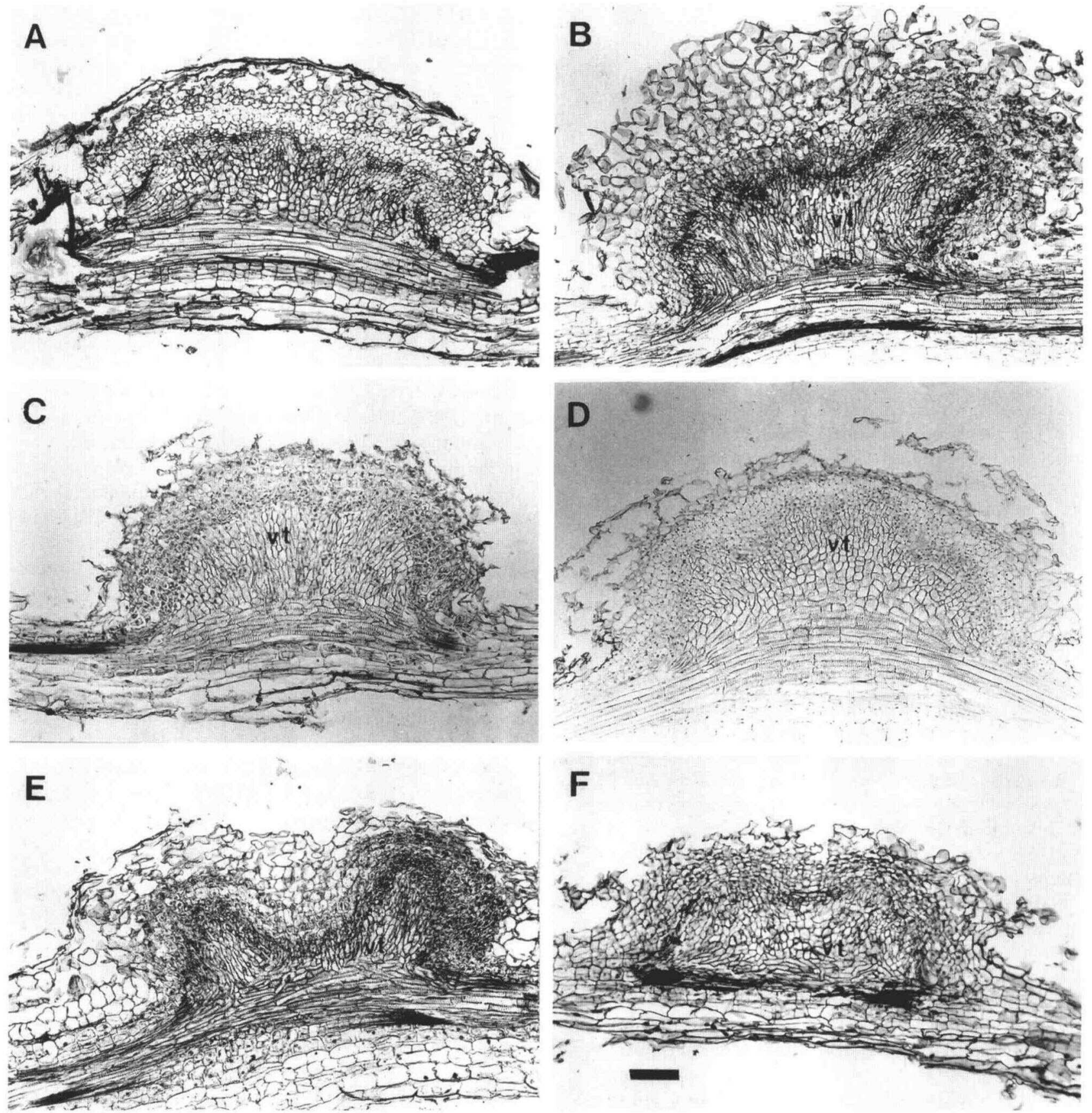

Figure 3. Longitudinal sections of NPA-elicited pseudonodules on sweetclover sym mutants. The pseudonodules were analyzed by paraffin serial sectioning and stained with saffranin/fast green 4 weeks after treatment with $20 \mu \mathrm{M}$ NPA. vt, Vascular tissue; bar $=100 \mu \mathrm{m}$. A, sym-1 allele BT58 (non-nodulating with $R$. meliloti); B, sym-1 allele BT62 (forms ineffective nodules with $R$. meliloti); C, sym-2 mutant BT59; D, sym-3 allele BT70; E, sym-5 mutant BT71; F, wild-type sweetclover.

in the current study because of insufficient seed. Together, these data suggested that different plant genes are required for infection thread formation than for $\mathrm{Had}^{+}$and nodule morphogenesis.

In the current study, we have extended our analysis of the sym loci of sweetclover to additional alleles of the sym-1 and sym-3 loci (Miller et al., 1991). Using large numbers of

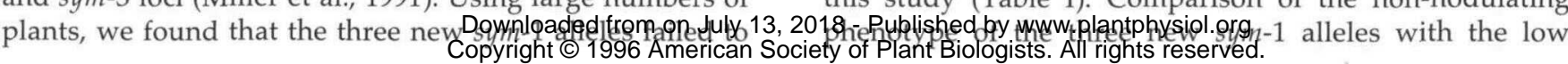

nodulate after inoculation with R. meliloti (Table I); we have also observed that two of these alleles, BT35 and BT58, exhibit a $\mathrm{Had}^{+}$response to R. meliloti (A.J. Cary and J.H. Norris, unpublished data). The BT62 sym-1 allele, previously characterized as $\mathrm{Had}^{+}$with ineffective nodules (Utrup et al., 1993), nodulated at a low frequency $(12 \%)$ in this study (Table I). Comparison of the non-nodulating 


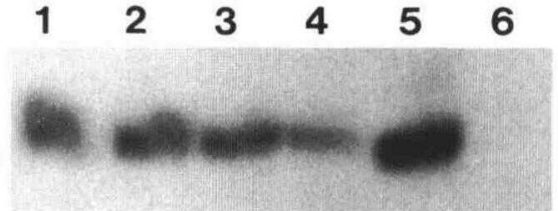

Figure 4. Expression of ENOD2 in NPA-elicited pseudonodules on sweetclover sym mutants. Approximately $10 \mu \mathrm{g}$ of total RNA were loaded in each lane of a gel probed with an ENOD2 clone from alfalfa labeled with digoxigenin-dUTP that hybridized to a $1.3-\mathrm{kb}$ transcript. Lane 1, RNA from nitrogen-fixing nodules inoculated with R. meliloti; lanes 2 to 5, RNA from NPA-elicited nodules on mutants: lane 2, sym-1 allele BT62; lane 3, sym-2 mutant; lane 4, sym-3 allele BT70; lane 5, sym-5 mutant; lane 6, RNA from noninoculated, untreated wild-type roots.

frequency of nodulation observed in BT62 suggests that allele BT62 may produce a small amount of functional gene product or the mutated gene product may be partially functional. We note that the nodules elicited on BT62 are white and ineffective rather than nitrogen fixing. This could be interpreted to mean that sym-1 is required for both nodule morphogenesis and infection, an explanation supported by the absence of infection threads in this mutant (Utrup et al., 1993).

All three mutant alleles in the sym-3 locus, BT61, BT69, and BT70, failed to form visible nodules after inoculation with $R$. meliloti (Table I), confirming our earlier observations of the BT70 allele (Utrup et al., 1993). To closely examine the possibility that limited cortical cell divisions might occur that fail to develop into visible nodule primordia, we carried out spot-inoculation assays on the BT70 allele, followed by serial sectioning of roots at several times after inoculation, following the method of Dudley et al. (1987). We found that BT70 demonstrated no cortical cell divisions in response to R. meliloti (Fig. 1), similar to the non-nodulating alfalfa mutant $\mathrm{MN}-1008$ (Dudley and Long, 1989). However, BT70 differs from MN-1008 in that BT70 displays a $\mathrm{Had}^{+}$response to $R$. meliloti, whereas MN-1008 shows no root-hair response (Dudley and Long, 1989). This suggests that the BT70 allele recognizes the bacterial NodRm-IV(S) signal in some limited fashion but lacks some secondary signal transduction event required to trigger cortical cell divisions.

All of the non-nodulating alleles in the sym-1 and sym-3 loci, including BT70, formed NPA-elicited pseudonodules at a high frequency. In addition, for all of the mutants that formed ineffective nodules in response to R. meliloti, sym-1 allele BT62 and mutants in the sym-2 and sym-5 loci, the frequency of formation of NPA-elicited pseudonodules was much higher than the frequency of nodulation observed after inoculation with $R$. meliloti.

The anatomy and structural characteristics of the NPAelicited pseudonodules on the sweetclover mutants appeared to be very similar to pseudonodules elicited by ATIs on alfalfa (Hirsch et al., 1989) and the intermediate-sized pseudonodules found on Afghanistan pea (Scheres et al., 1992). The sweetclover pseudonodules were spherical or multilobed in shape but lacked the distinct apical meristem normally found

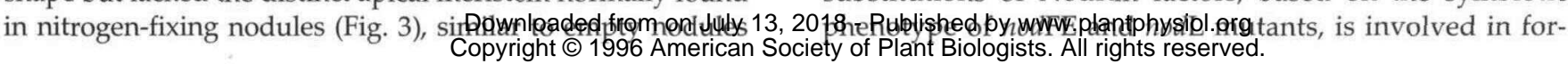

elicited by exo mutants of R. meliloti (Yang et al., 1992). Rather than the peripheral vascular bundles found in nitrogen-fixing nodules, the pseudonodules contained a broad, proximal region of vascular tissue. Although some structural differences were observed in the pseudonodules on different mutants, no conclusions are possible until tissues in the NPA-elicited pseudonodules are further characterized by in situ hybridization.

The early nodulin ENOD2, expressed in cells of the nodule parenchyma along the periphery of the nodule in pea, soybean, and alfalfa nodules (Van de Wiel et al., 1990a, 1990b), has been used as a molecular marker for the development of nodule parenchyma tissue in pseudonodules elicited by ATIs on alfalfa and Afghanistan pea (Scheres et al., 1992) and in nodules elicited by $R$. meliloti nodulation mutants carrying a trans-zeatin secretion gene (Cooper and Long, 1994). ENOD2 was expressed in the NPA-elicited pseudonodules on all of the sweetclover mutants, as detected by blot hybridization, indicating that these pseudonodules share at least some of the developmental characteristics of nodules elicited by $R$. meliloti. We also detected expression of ENOD8 (Dickstein et al., 1993) in NPA-elicited pseudonodules on all of the sweetclover mutants described here (C. Wu, R. Dickstein, A.J. Cary, and J.H. Norris, unpublished data).

The finding of formation of pseudonodules on allelic non-nodulating mutants from the sym-1 and sym-3 loci of sweetclover after treatment with the ATI NPA contributes to a growing body of evidence that the bacterial Nod factors may cause perturbations in endogenous plant hormone levels. We speculate, as was suggested previously by Hirsch et al. (1989), that the ATI NPA may be mimicking a secondary signal required for nodule organogenesis, resulting in the formation of pseudonodules on all of the mutants. The possibility that this signal involves an increase in the cytokinin-to-auxin ratio in the root cortex tissue is suggested by both pseudonodules elicited by ATIs (Hirsch et al., 1989; Scheres et al., 1992; this study) and nodules elicited by $R$. meliloti nodulation mutants carrying a trans-zeatin secretion gene (Cooper and Long, 1994), although some differences in the characteristics of these nodules remain to be resolved (Cooper and Long, 1994). The fact that alleles in both the sym-1 and sym-3 loci that are non-nodulating with $R$. meliloti form pseudonodules after NPA treatment indicates that at least two plant genes act upstream of this point in signal transduction leading to nodule organogenesis.

Recently, Ardourel et al. (1994) proposed a model for the role of $R$. meliloti Nod factors in which two root-hair receptors of differing stringency for recognition of Nod factors activate two signal transduction pathways, both required for nodule morphogenesis. The putative "signaling receptor" pathway, involved in cell-wall tip growth and cortical cell activation, is responsible for the $\mathrm{Had}^{+}$response to $\operatorname{nod} \mathrm{F} / \operatorname{nod} \mathrm{L}$ mutants of $R$. meliloti, accompanied by cortical cell activation but no nodules. The proposed "entry receptor" pathway of greater stringency for the nonreducing end substitutions of NodRm factors, based on the symbiotic 
mation of infection sites and infection thread development (Ardourel et al., 1994). The phenotypic response of the sweetclover sym mutants to $R$. meliloti, characterized in this study and by Utrup et al. (1993), supports this model with the following interpretation and modification.

The $\mathrm{Had}^{+}$phenotype of the sym-3 allele BT70, in which no cortical cell divisions were observed, would indicate that the signaling receptor pathway is intact in this mutant to the extent of allowing root-hair deformations, but the remainder of the pathway leading to cortical cell activation is blocked. But the mutant also fails to form a $\mathrm{Hac}^{+} / \mathrm{Inf}$ response through the entry receptor pathway, even though genetic analysis indicates that all of the sweetclover mutants are monogenic and recessive (Miller et al., 1991). Based on this observation, we propose that the signal receptor pathway must activate the entry receptor pathway for the more stringent response to Nod factor to occur, leading to root-hair curling and infection thread development. The sym-3 BT70 allele and possibly the $\mathrm{Had}^{+}$, nonnodulating sym-1 alleles must be blocked in the signaling receptor pathway prior to the point of activation of the entry receptor pathway. In comparison, the $\mathrm{Hac}^{+}$, nonnodulating sym-4 mutant (Utrup et al., 1993) may be blocked late in the signaling receptor pathway, before cortical cell activation but after the entry receptor pathway leading to formation of infection threads has been activated. It will be of great interest to determine whether cortical cell activation occurs in the sym-4 mutant and the non-nodulating sym-1 alleles.

The $\mathrm{Had}^{+}$sym-5 mutant, which forms ineffective nodules, appears to have an intact signaling receptor pathway, but may be blocked in the entry receptor pathway, so that root-hair curling and infection thread formation do not occur. The $\mathrm{Hac}^{+}$sym-2 mutant, in which infection threads and ineffective nodules are observed, appears to be blocked late in the entry receptor pathway. These hypotheses regarding the relationship of the sweetclover sym genes to the two-receptor model of Ardourel et al. (1994) could be tested in part by construction of double mutants, such as a sym-4/sym-5 mutant, in which an additive phenotype ( $\mathrm{Had}^{+}$and non-nodulating) would support the model, and an epistatic effect would suggest a single signal transduction pathway. We are also investigating the hypothesis that a defense response occurs in the sweetclover mutants after inoculation with $R$. meliloti, as elaborated in the model recently proposed by Mellor and Collinge (1995).

We suggest that the ATI NPA may be circumventing a secondary signal of plant origin in the signaling receptor pathway (Ardourel et al., 1994) that is required for cortical cell activation and nodule organogenesis, resulting in the formation of pseudonodules. This signal is normally missing in the sym-3 alleles and possibly in the non-nodulating sym-1 alleles, which form pseudonodules only in the presence of NPA. The fact that these mutants form pseudonodules rather than simply exhibiting cortical cell activation, as did alfalfa plants inoculated with a nod $\mathrm{F} / \operatorname{nod} \mathrm{L}$ mutant of $R$. meliloti (Ardourel et al., 1994), suggests that the factor mimicked by NPA may be limiting in the plants inoculated with the nod $\mathrm{F} /$ nod $\mathrm{L}$ mutant, which do nodulate at a very low frequency (Ardourel et al., 1994). Alternatively, the formation of ATI-elicited pseudonodules, as well as nodules elicited by bacteria carrying a trans-zeatin secretion gene (Cooper and Long, 1994), may indicate that cross-talk occurs between the signaling receptor pathway and the entry receptor pathway to trigger nodule morphogenesis following cortical cell activation. Based on the data presented here, we propose that the products of the sym-1 and sym-3 genes of sweetclover are required for plantregulated steps of the signaling receptor transduction pathway (Ardourel et al., 1994). Further characterization of the sweetclover sym mutants should assist in elucidation of the signal transduction pathways leading to nodule organogenesis.

\section{ACKNOWLEDGMENTS}

The authors would like to thank Dr. Tom LaRue for providing the mutants used in this study and for many helpful discussions. We would also like to thank Dr. Edward Carney for assistance with statistical evaluation of the data.

Received August 21, 1995; accepted October 20, 1995.

Copyright Clearance Center: 0032-0889/96/110/0501/10.

\section{LITERATURE CITED}

Akao S, Nakata S, Yoneyama T (1991) Formation of nodules on non-nodulating soybean T201 after treatment with 2,4-dichlorophenoxyacetate. Plant Soil 138: 207-212

Allen EK, Allen ON, Newman AS (1953) Pseudonodulation of leguminous plants induced by 2-bromo-3,5-dichlorobenzoic acid. Am J Bot 40: 429-435

Allen T, Raja S, Dunn K (1991) Cells expressing ENOD2 show differential spatial organization during the development of alfalfa root nodules. Mol Plant-Microbe Interact 4: 139-146

Ardourel M, Demont N, Debelle F, Maillet F, de Billy F, Prome J-C, Denarie J, Truchet G (1994) Rhizobium meliloti lipooligosaccharide nodulation factors: different structural requirements for bacterial entry into target root hair cells and induction of plant symbiotic developmental responses. Plant Cell 6: 1357-1374

Blauenfeldt J, Joshi PA, Gresshoff PM, Caetano-Anollés G (1994) Nodulation of white clover (Trifolium repens) in the absence of Rhizobium. Protoplasma 179: 106-110

Caetano-Anollés G, Joshi PA, Gresshoff PM (1990) Spontaneous nodules induce feedback suppression of nodulation in alfalfa. Planta 183: 77-82

Calvert HE, Pence MK, Pierce M, Malik NSA, Bauer WD (1984) Anatomical analysis of the development and distribution of Rhizobium infections in soybean roots. Can J Bot 30: 2375-2384

Carlson RW, Price NPJ, Stacey G (1994) The biosynthesis of rhizobial lipo-oligosaccharide nodulation signal molecules. Mol Plant-Microbe Interact 7: 684-695

Cook D, Dreyer D, Bonnet D, Howell M, Nony E, VandenBosch K (1995) Transient induction of a peroxidase gene in Medicago truncatula precedes infection by Rhizobium meliloti. Plant Cell 7: 43-55

Cooper JB, Long SR (1994) Morphogenetic rescue of Rhizobium meliloti nodulation mutants by trans-zeatin secretion. Plant Cell 6: $215-225$

Dehio C, de Bruijn FJ (1992) The early nodulin gene SrENOD2 from Sesbania rostrata is inducible by cytokinin. Plant J 2: 117-128

De Jong AJ, Heidstra R, Spaink HP, Hartog MV, Meijer EA, Hendriks T, Schiavo FL, Terzi M, Bisseling T, Van Kammen A, De Vries SC (1993) Rhizobium lipooligosaccharides rescue a carrot somatic embryo mutant. Plant Cell 5: 615-620

Denarie J, Roche P (1992) Rhizobium nodulation signals. In DPS Verma, ed, Molecular Signals in Plant-Microbe Communications. CRC Press, Boca Raton, FL, pp 295-324 
Dickstein R, Bisseling T, Reingold UN, Ausubel FM (1988) Expression of nodule-specific genes in alfalfa root nodules blocked at an early stage of development. Genes Dev 2: 677-687

Dickstein R, Prusty R, Peng T, Ngo W, Smith ME (1993) ENOD8, a novel early nodule-specific gene, is expressed in empty alfalfa nodules. Mol Plant-Microbe Interact 6: 715-721

Dudley ME, Jacobs TW, Long SR (1987) Microscopic studies of cell divisions induced in alfalfa roots by Rhizobium meliloti. Planta (Berl) 171: 289-301

Dudley ME, Long SR (1989) Non-nodulating alfalfa mutant displays neither root hair curling nor early cell division in response to Rhizobium meliloti. Plant Cell 1: 65-72

Ehrhardt DW, Atkinson EM, Long SR (1992) Depolarization of alfalfa root hair membrane potential by Rhizobium meliloti Nod factors. Science 256: 998-1000

Finney DJ (1980) Significance, binomials, and $\chi^{2}$. In Statistics for Biologists. Chapman and Hall, New York, pp 43-45

Govers F, Gloudemans T, Moerman M, Van Kammen A, Bisseling $T$ (1985) Expression of plant genes during the development of pea root nodules. EMBO J 4: 861-867

Heidstra R, Geurts R, Franssen H, Spaink HP, Van Kammen A, Bisseling T (1994) Root hair deformation activity of nodulation factors and their fate on Vicia sativa. Plant Physiol 105: 787-797

Hirsch AM (1992) Developmental biology of legume nodulation. New Phytol 122: 211-237

Hirsch AM, Bhuvaneswari TV, Torrey JG, Bisseling T (1989) Early nodulin genes are induced in alfalfa root outgrowths elicited by auxin transport inhibitors. Proc Natl Acad Sci USA 86: $1244-1248$

Hirsch AM, Fang Y (1994) Plant hormones and nodulation: what's the connection? Plant Mol Biol 26: 5-9

Jensen WA (1962) Quantitative histochemistry. In Botanical Histochemistry. WH Freeman and Co, San Francisco, CA, pp 1-39

Kneen BE, LaRue TA (1988) Induced symbiosis mutants of pea (Pisum sativum) and sweetclover (Melilotus alba annua). Plant Sci 58: $177-182$

Kosslak RM, Bookland IR, Barkei J, Paaren HE, Applebaum ER (1987) Induction of Bradyrhizobium japonicum common nod genes by isoflavones isolated from Glycine max. Proc Natl Acad Sci USA 84: 7428-7432

Lerouge P, Roche P, Faucher C, Maillet F, Truchet G, Prome JC, Denarie J (1990) Symbiotic host-specificity of Rhizobium meliloti is determined by a sulphated and acylated glucosamine oligosaccharide signal. Nature 344: 781-784

Libbenga KR, Bogers RJ (1974) Root nodule morphogenesis. In A Quispel, ed, The Biology of Nitrogen Fixation. North-Holland, Amsterdam, The Netherlands, pp 430-472

Libbenga KR, Van Iren F, Bogers RJ, Schraag-Lamers MF (1973) The role of hormones and gradients in the initiation of cortex proliferation and nodule formation in Pisum satioum L. Planta 114: $29-39$

Long SR (1992) Genetic analysis of Rhizobium nodulation. In G Stacey, RH Burris, HJ Evans, eds, Biological Nitrogen Fixation. Chapman and Hall, New York, pp 560-597

Maxwell CA, Hartwig UA, Joseph CM, Phillips DA (1989) A chalcone and two related flavonoids released from alfalfa roots induce nod genes of Rhizobium meliloti. Plant Physiol 91: 842-847

Mellor RB, Collinge DB (1995) A simple model based on known plant defense reactions is sufficient to explain most aspects of nodulation. J Exp Bot 46: 1-18

Miller JE, Viands DR, LaRue TA (1991) Inheritance of nonnodulating mutants of sweetclover. Crop Sci 31: 948-952

Peters NK, Frost JW, Long SR (1986) A plant flavone, luteolin, induces expression of Rhizobium meliloti nodulation genes. Science 223: 977-980
Pichon M, Journet E-P, de Billy F, Dedieu A, Huguet T, Truchet G, Barker DG (1994) ENOD12 gene expression as a molecular marker for comparing Rhizobium-dependent and -independent nodulation in alfalfa. Mol Plant-Microbe Interact 7: $740-747$

Pichon M, Journet E-P, Dedieu A, de Billy F, Truchet G, Barker DG (1992) Rhizobium meliloti elicits transient expression of the early nodulin gene ENOD12 in the differentiating root epidermis of transgenic alfalfa. Plant Cell 4: 1199-1211

Sambrook J, Fritsch EF, Maniatis T (1989) Electrophoresis of RNA through gels containing formaldehyde. In Molecular: Cloning, A Laboratory Manual, Ed 2, Vol 1. Cold Spring Harbor Laboratory Press, Cold Spring Harbor, NY, pp 7.43-7.45

Scheres B, McKhann HI, Zalensky A, Lobler M, Bisseling T, Hirsch AM (1992) The PsENOD12 gene is expressed at two different sites in Afghanistan pea pseudonodules induced by auxin transport inhibitors. Plant Physiol 100: 1649-1655

Scheres B, Van de Wiel C, Zalensky A, Horvath B, Spaink H, Van Eck H, Zwartkruis F, Wolters AM, Gloudemans T, Van Kammen A, Bisseling T (1990a) The ENOD12 gene product is involved in the infection process during pea-Rhizobium interaction. Cell 60: 281-294

Scheres B, Van Engelen F, Van der Knaap E, Van de Wiel C, Van Kammen A, Bisseling T (1990b) Sequential induction of nodulin gene expression in the developing pea nodule. Plant Cell 2: $687-700$

Thimann KV (1936) On the physiology of the formation of nodules on legume roots. Proc Natl Acad Sci USA 22: 511-515

Truchet G, Barker DG, Camut S, de Billy F, Vasse J, Huguet T (1989) Alfalfa nodulation in the absence of Rhizobium. Mol Gen Genet 219: 65-68

Truchet G, Roche P, Lerouge P, Vasse J, Camut S, de Billy F, Prome J, Denarie J (1991) Sulphated lipo-oligosaccharide signals of Rhizobium meliloti elicit root nodule organogenesis in alfalfa. Nature 351: 670-673

Turgeon BG, Bauer WD (1982) Early events in the infection of soybean by Rhizobium japonicum: time course and cytology of the initial infection process. Can J Bot 60: 152-161

Utrup LJ, Cary AJ, Norris JH (1993) Five nodulation mutants of white sweetclover (Melilotus alba Desr.) exhibit distinct phenotypes blocked at root hair curling, infection thread development, and nodule organogenesis. Plant Physiol 103: 925-932

Van de Wiel C, Norris JH, Bochenek B, Dickstein R, Bisseling T, Hirsch AM (1990a) Nodulin gene expression and ENOD2 localization in effective, nitrogen-fixing and ineffective, bacteria-free nodules of alfalfa. Plant Cell 2: 1009-1017

Van de Wiel C, Scheres B, Franssen H, Van Leirop M-J, Van Lammeren A, Van Kammen A, Bisseling T (1990b) The early nodulin transcript ENOD2 is located in the nodule parenchyma (inner cortex) of pea and soybean root nodules. EMBO J 9: $1-7$

Vasse J, de Billy F, Camut S, Truchet G (1990) Correlation between ultrastructural differentiation of bacteroids and nitrogen fixation in alfalfa nodules. J Bacteriol 172: 4295-4306

Vincent JM (1970) A Manual for the Practical Study of Root Nodule Bacteria. Blackwell Scientific, Oxford, UK, p 75

Yang C, Signer ER, Hirsch AM (1992) Nodules initiated by Rhizobium meliloti exopolysaccharide mutants lack a discrete, persistent nodule meristem. Plant Physiol 98: 143-151

Yang W-C, de Blank C, Meskiene I, Hirt H, Bakker J, Van Kammen A, Franssen H, Bisseling T (1994) Rhizobium Nod factors reactivate the cell cycle during infection and nodule primordium formation, but the cycle is only completed in primordium formation. Plant Cell 6: 1415-1426 